\title{
Exchange Rate Volatility and the Performance of Manufacturing Sector in Nigeria: An Econometric Analysis
}

Chinonye Emmanuel Onwuka ( $\square$ emmanuelonwuka15@gmail.com )

\section{Research}

Keywords: Exchange rate volatility, manufacturing performance, ARCH/GARCH model, ARDL, Nigeria

Posted Date: March 7th, 2022

DOI: https://doi.org/10.21203/rs.3.rs-1111246/v1

License: (c) (i) This work is licensed under a Creative Commons Attribution 4.0 International License.

Read Full License 


\title{
EXCHANGE RATE VOLATILITY AND THE PERFORMANCE OF MANUFACTURING SECTOR IN NIGERIA
}

(1981-2020)

\author{
Chinonye Emmanuel Onwuka
}

Tel: +2348100543232

E-mail: emmanuelonwuka15@gmail.com

\begin{abstract}
This study examined the impact of exchange rate volatility on the performance of manufacturing sector in Nigeria from 1981 to 2020 using ARCH/GARCH model and Autoregressive Distributed Lag Model (ARDL). The ARCH/GARCH model confirms that there is a high exchange rate volatility which was validated by their coefficients which were positive and statistically significant at 1\% level. The Augmented Dickey Fuller (ADF) unit root test results showed that all the variables were stationary at first difference and the Bound test confirmed a long run relationship among the variables. The ARDL results show that exchange rate volatility, interest rate and inflation rate has a negative impact on the performance of manufacturing sector in the long run while import and gross capital formation have a positive effect on manufacturing performance in the long run. Also, exchange rate volatility, gross capital formation and interest rate were found to have a significant impact on manufacturing performance while import and inflation were found to be non-significant. The findings also show that in the short run that volatility in exchange rate is negatively and significantly related to the performance of manufacturing sector in Nigeria. Furthermore, the coefficient of error correction term shows that about 66 percent of the disparity between the actual and the equilibrium value of manufacturing performance is corrected every year. The study concludes that monetary authorities should formulate a policy framework that will be targeted at improving and stabilizing naira exchange rate. Also, Nigerian government should appropriate more funds to the manufacturing sector. Finally, interest on lending should be reduced to barest minimal to encourage investment both locally and internationally.
\end{abstract}

Keywords: Exchange rate volatility, manufacturing performance, ARCH/GARCH model, $A R D L$, Nigeria.

JEL classification code: C01, C22, F31, 014. 


\section{Introduction}

Manufacturing sector is one of the key sectors of many economies globally. It is a quest for improvement in production in association to import substitution and creating foreign exchange earnings capacity (Fakiyesi, 2015). Manufacturing is the production of goods through the application of labour, machines and tools. It involves both manpower and high technology through which raw materials are converted into finished product (Adofu, Taiga \& Tijani, 2015).

Exchange rate is a vital tool used in the determination of the international competitiveness of a nation. Exchange rate is the rate at which one currency is exchanged for another. Exchange rate is determined by the interaction of demand and supply of foreign exchange. Thus, if demand for a currency rises with the supply being constant, the exchange rate of the currency will appreciate. But if the demand for the currency falls with the supply remaining constant, the exchange rate will depreciate (Ezenwakwelu, 2017).

In an effort to enhance the performance of the manufacturing sector of Nigeria and also deal with other challenges that affects its operations, the Structural Adjustment Programme (SAP) was introduced in 1986. A critical component of SAP was the exchange rate deregulation which was intended to make foreign exchange more accessible for production thereby increasing manufacturing output and employment while reducing inflation (Adegbemi, 2018). The programme envisaged improving the performance of the manufacturing sector by reducing import dependence and promoting manufacturing for export. One of the major objectives of the reform was exchange rate deregulation which allowed exchange rate determination to be market driven (Nwokoro, 2017).

Statistically, exchange rate in Nigeria was 1.75 per USD in 1986 to 8.04 per USD in 1990. It increased to 21.9 and 92.34 per USD per cent in 1995 and 1999 respectively, the exchange rate moved to 120.58 per USD in 2002 to 131.27 per USD in 2005. It further rose to 150.3 per USD and 158.55 in 2010 and 2014 respectively. The trend rose from 305.79 per USD in 2017 to 358.8 per USD in 2020 (WDI, 2020). Also, an examination of manufacturing sector share in the GDP in recent years shows that it has not been relatively stable. In 1990, it was about 5.5\% while it dropped to $2.22 \%$ in 2010 . It grew to $7.18 \%$ in 2011 to $7.79 \%$ in 2013 . It further rose to $9.53 \%$ in 2015 and to $8.860 \%$ in 2018 and further rose to $13.01 \%$ in 2020 (WDI, 2020).

The critical challenge faced by Nigerian manufacturing industry is inadequate raw material for production of finished products. This condition tends to affect negatively the productivity level of 
the sector (Okorontah \& Odoemena, 2016). The ability of the manufacturing industry to imports input materials depend on the level of the exchange rates. It is evident that most organisations source their inputs externally. Hence, the devaluation or depreciation of exchange rate tends to impede the performance of the sector (Nsofo, Takson \& Ugwuegbe, 2017).

The link between exchange rate volatility and the performance of manufacturing sector have been examined by various studies (such as Enekwe, Ordu \& Abu, 2013; Akinlo \& Adejumo, 2014; Alabi, 2014; Lawal, 2016; Nwokoro, 2017; Nsofo, Takson \& Ugwuegbe, 2017; Ugwu, 2017; Adegbemi, 2018; Falaye et al. 2018; Hunegnaw, 2018; Oriji et al., 2019) in both developed and developing countries. For instance, studies such as Falaye et al. (2018) and Nwokoro (2017) showed that exchange rate volatility has a negative and significant effect on manufacturing sector.

Furthermore, the findings of Akinlo and Adejumo (2014); Lawal (2016) and Oriji et al. (2019) found a positive and significant impact of exchange rate on the performance of manufacturing sector. However, King-George (2013) found that exchange rate volatility has no significant effect on manufacturing sector in Nigeria. The differences in their findings call for further investigation. Hence, it is against this backdrop that this study seeks to examine the impact of exchange rate volatility on manufacturing sector performance in Nigeria.

The other sections of this paper are arranged as follows; Section two review theoretical and empirical literatures. The third section focuses on methodology. Section four looks at the presentation and analysis of results while the final section provides conclusion and recommendations.

\section{Literature Review}

\section{$2.1 \quad$ Theoretical Framework}

The theoretical framework for the study is based on Mundell-Fleming IS-LM BOP Model approach. The IS-LM BOP model portrayed a relationship between exchange rate, interest rate and output of an open economy. It is an extension of IS-LM framework which deals with a close economy. The model is expressed as follows;

The investment-saving (IS) curve describes the combination of both income $(Y)$ and the interest rate $(r)$;

$Y=C(Y-T)+I(r)+G$ 
Assuming a linear consumption function, investment function and the behavioral equation for net export we have;

$Y=C+I+G+\mathrm{N}_{\mathrm{x}}$

Given that the consumption function is;

$C=a+b(Y-T)$

Where $a>0 \quad b>0$, and the investment function is;

$I=c-d r$

Where: $\mathrm{b}=$ the marginal propensity to consume $(0<b<1) ; d=$ marginal propensity to invest $(d<0)$.

The behavioural equation for net export $\left(\mathrm{N}_{\mathrm{x}}\right)$ or the trade balance is;

$\mathrm{N}_{\mathrm{x}}=E e_{r}^{\gamma}-e_{r} \mathrm{mY}$

Given the real exchange rate is;

$e_{r}=\mathrm{ep}^{*} / \mathrm{P}$

Where: $\mathrm{e}=$ nominal exchange rate; $\mathrm{P}^{*}=$ foreign price; $\mathrm{P}=$ domestic price level (GDP deflator); $\mathrm{m}=$ the marginal propensity to import and $\gamma=$ the responsiveness of exports to real exchange rate.

The $L M$ curve describes the combinations of income $Y$ and the interest rate $r$ that satisfy the money market equilibrium condition;

$M / P=\mathrm{k} Y-L(\mathrm{r}, Y)$.

$r=\left(i-i^{*}\right)$

Where: $\mathrm{k}=$ transaction coefficient; $\mathrm{L}=$ the speculative coefficient; $\mathrm{i}^{*}=$ the foreign interest rate; $\mathrm{M}$ $=$ the money supply and $\mathrm{P}=$ the price level.

The BP curve captures the balance of payment in the model. It is the sum of the current account balance and capital account balance. The equation is satisfied when the change in reserve is zero;

$N_{x}+F\left(i-i^{*}\right)=0$

Where $\mathrm{F}=$ the capital flow parameter. 
Finally, assuming a flexible exchange rate, to find the aggregate demand equation, we must find the level of income that satisfies the combination of IS cuve, LM curve and BP curve. To do this, substitute the $L M$ equation for the interest rate $r$ and BP equation for the interest rate $i$ into the IS equation to obtain;

From the BP curve, multiple BP curve by $a$ to get;

$$
a \mathrm{~N}_{\mathrm{x}}=a \mathrm{~F}\left(\mathrm{i}-\mathrm{i}^{*}\right)
$$

Next substitute into the IS curve to get an expression in $\mathrm{Y}$ and $\mathrm{i}$

$\mathrm{Y}=a \mathrm{~A}-a \mathrm{bi}-a \mathrm{~F}\left(\mathrm{i}-\mathrm{i}^{*}\right)$

Combining terms with $\mathrm{i}$;

$\mathrm{Y}=a \mathrm{~A}-a(b+F) \mathrm{i}-a \mathrm{~F}\left(\mathrm{i}^{\star}\right)$

From the LM curve;

$k Y-L\left(i-i^{*}\right)=M / P$

$\mathrm{i}=(\mathrm{k} / \mathrm{L}) \mathrm{Y}-\mathrm{M} / \mathrm{PL}+\mathrm{i}^{*}$

And substitute into the IS curve;

$\mathrm{Y}=a \mathrm{~A}-a(\mathrm{~b}+\mathrm{F}) \mathrm{k} / \mathrm{L}) \mathrm{Y}+a(\mathrm{~b}+\mathrm{F}) \mathrm{M} / \mathrm{PL}--a(b+F) i *+a \mathrm{Fi}^{*}$

Simplifying;

$[1+a(\mathrm{~b}+\mathrm{F})(\mathrm{k} / \mathrm{h})] \mathrm{Y}=a\left[\mathrm{~A}+(\mathrm{b}+\mathrm{F}) \mathrm{M} / \mathrm{PL}-\mathrm{Bi}^{*}\right]$

$Y=\frac{a\left[A+\frac{(b+F) M}{P L}-b i *\right]}{\left[1+a(b+F)\left(\frac{k}{L}\right)\right]}$

\subsection{Empirical Review}

Enekwe, Ordu, and Nwoha (2013) examined the effect of exchange rate fluctuations on the manufacturing sector in Nigeria from 1985 to 2010 using regression analysis. The results showed that exchange rate fluctuation has a significantly positive relationship with the manufacturing sector of Nigeria. The researchers recommended export diversification in agriculture, agro-allied industries and agro investment as this would improve the development of the manufacturing sector. King-George (2013) examined the effect of exchange rate fluctuations on the Nigeria manufacturing sector, using annual time series data for the period 1986 to 2010. Employing the Ordinary Least Square (OLS) techniques, the results showed that exchange rate 
has no significant effect on the growth of the Nigerian economy. Alabi (2014) investigate the effect of real exchange rate fluctuation on Industrial Output in Nigeria using the OLS regression analysis. The results showed a positive bidirectional relationship between exchange rate and output in Nigeria and other resource dependent economies. They conclude that industrial output in Nigeria can be determined by movement in real exchange rate, capital utilization ratio, technology and available foreign exchange. Akinlo and Lawal (2015) investigated the impact of exchange rate on industrial production for the period 1986-2010. The study employed the used of Vector Error Correction Model (VECM). The findings show that there is long run relationship among exchange rate, industrial production index, inflation rate and money supply. The results also show that exchange rate depreciation does not have significant effect on industrial production in the short run; however, in the long run, the results showed that exchange rate depreciation had significant effect on the industrial production in Nigeria. Lawal (2016) examined the effect of exchange rate fluctuations on the performance of Nigerian manufacturing sector for the period 1986-2014 using Autoregressive Distribution Lag (ARDL) model. The findings of the ARDL revealed evidence of long run and short run relationships among the variables under consideration. The result also showed that exchange rate has positive and significant effect on manufacturing sector output. Nwokoro (2017) assessed the effect of exchange rate and interest rates fluctuations on the manufacturing output in Nigeria from the period 1983-2014 using Error Correction Modeling (ECM). The findings showed that exchange rate and interest rates have negative and significant influence on manufacturing Output. Ugwu (2017) investigate the impact of exchange rate fluctuation on manufacturing performance in Nigeria for the period 1986-2016 using Ordinary Least Squares (OLS) technique. The findings revealed that a significant relationship exists between exchange rate fluctuations and manufacturing performance in Nigeria. Adegbemi (2018) examined the effect of the changes in the macroeconomic factors on the manufacturing sector performance in Nigeria for the period 1981-2015. The findings indicated a negative relationship among interest rate, inflation rate, broad money supply, exchange rate and manufacturing performance. The interest rate and inflation rate were found to be statistically non-significant. The result also showed that gross domestic product and unemployment have positive and significant impact manufacturing performance in Nigeria. Falaye et al. (2018) assessed the impact of exchange rates on the performance of the Nigerian manufacturing sector over a period of 25 years using Error Correction Model (ECM). The empirical findings showed that devaluation of the Naira had a negative impact on the performance of the Nigerian manufacturing sector. Hunegnaw (2018) examined the effects of real exchange rates on manufacturing exports in 10 East African 
countries. The study used pooled mean group and mean group estimators with an Autoregressive Distributed Lag procedure to analyze disaggregated manufacturing exports, unlike past studies that often examined aggregate exports by adopting traditional empirical methods subject to various shortcomings. Findings suggest that exchange rate devaluation matters for export performance in Eastern Africa. Oriji et al. (2019) examined the impact of exchange rate $(E X C H)$ movements on the manufacturing sector in Nigeria over the period 1981-2016. An ordinary least square (OLS) estimation technique was employed in this study to address the specified objective. Specifically, the findings showed that EXCH, government capital expenditure (GCEXP), imports and FDI were positively related to MGDP.

\section{Methodology}

\subsection{Model Specification}

Following the Mundell-Fleming IS-LM BOP Model in the above equations, a suitable model would be modified to examine exchange rate volatility and manufacturing sector performance in Nigeria. Recall that the IS-LM BOP model shows a relationship between exchange rate, interest rate and output of the economy. Building on this, the model for the study can be modified as;

$M A N=f(E X R V O R$, INTR, IMP, GCF, INFL)

The econometric form of the model above is stated as;

MAN $_{t}=\beta_{0}+\beta_{1} E X R V O L_{t}+\beta_{2} I N T R_{t}+\beta_{3} I M P P_{t}+\beta_{4} \mathrm{GCF}_{t}+\beta_{5} \mathrm{INFL}_{t}+\mathrm{U}_{t}$

Where;

MAN = manufacturing Performance (proxied by \% of manufacturing sector to GDP)

$\mathrm{EXRVOI}=$ Exchange rate Volatility

INTR = Interest rate

IMPT = Import

GCF $=$ Gross capital formation

$\mathrm{INFL}=$ inflation rate

$\mathrm{U}_{\mathrm{t}}=$ stochastic error term

$\beta_{0}=$ constant term

$\beta_{1}$ to $\beta_{5}=$ coefficients of the variables

\subsection{Data and Sources}


The study employed the use of time series secondary data sourced from the Central Bank of Nigeria (CBN) and National Bureau of Statistics (NBS) between the periods 1981 to 2020.

\subsection{Estimation Technique}

In order to determine the volatility of naira exchange rate for the period under study, the study applied the use of Generalised Autoregressive Conditional Heteroscedasticity (GARCH) Models. The choice of the model is based on the fact that the GARCH model is very reliable in modeling the volatility of financial data.

Finally, to establish the impact of exchange rate volatility on manufacturing performance in Nigeria the study adopted an Autoregressive Distributed Lag (ARDL). However, the ARDL model has difficulties in identifying the relationships between the data variables which contain a unit root as issues of spurious correlation may occur. Therefore, modeling the variables in difference may be used to avoid problem relating to unit root. Finally, the ARDL model is employed to ascertain long-run equilibrium between the variables

\section{Presentation and Analysis of Results}

\subsection{ARCH Effect}

In order to ascertain whether exchange rate is volatile over the periods of study, the residual from the exchange rate volatility model using the $\operatorname{GARCH}(1,1)$ must satisfy two conditions. That is, it must have an ARCH effect, and the volatility must be clustered otherwise the variable is not volatile.

4.1.1 Confirmation of the presence of ARCH effect Table 1: Heteroskedasticity test: ARCH Test result

Heteroskedasticity test: ARCH Test

\begin{tabular}{|l|l|l|l|}
\hline F-statistic & 22.61710 & Prob. F(1,35) & 0.0000 \\
\hline Obs ${ }^{\star}$ R-squared & 14.52403 & Prob. Chi-Square(1) & 0.0001 \\
\hline
\end{tabular}

Source: Authors' Computations using Eviews 10.0, 2021.

$\mathrm{H}_{0}$ : There is no ARCH effect

$\mathrm{H}_{1}$ : There is $\mathrm{ARCH}$ effect 


\section{Decision Rule}

Probabilities $>0.05$ accept the null hypothesis

Probabilities $<0.05$ reject the null hypothesis

Table 1 above shows the result of the Auto-Regressive Conditional Heteroskedasticity (ARCH) effect. The findings show that F-statistic is statistically significant at $5 \%$ level since the probability value is less than 0.05 . This indicates that we reject the null hypothesis and accept alternative hypothesis which stated that there is ARCH effect.

Table 2: Correlogram Q-statistics

\begin{tabular}{|r|r|r|r|l|}
\hline & $\begin{array}{c}\text { Autocorrelation } \\
\text { (AC) }\end{array}$ & $\begin{array}{c}\text { Partial Correlation } \\
\text { (PAC) }\end{array}$ & Q-Stat & Prob $^{* *}$ \\
\hline 1 & 0.882 & 0.882 & 33.514 & 0.000 \\
\hline 2 & 0.782 & 0.019 & 60.559 & 0.000 \\
\hline 3 & 0.676 & -0.08 & 81.285 & 0.000 \\
\hline 4 & 0.56 & -0.109 & 95.915 & 0.000 \\
\hline 5 & 0.468 & 0.03 & 106.44 & 0.000 \\
\hline 6 & 0.41 & 0.109 & 114.76 & 0.000 \\
\hline 7 & 0.371 & 0.058 & 121.76 & 0.000 \\
\hline 8 & 0.326 & -0.065 & 127.35 & 0.000 \\
\hline 9 & 0.279 & -0.073 & 131.56 & 0.000 \\
\hline 10 & 0.234 & -0.008 & 134.64 & 0.000 \\
\hline 11 & 0.187 & -0.005 & 136.67 & 0.000 \\
\hline 12 & 0.138 & -0.027 & 137.82 & 0.000 \\
\hline 13 & 0.109 & 0.038 & 138.56 & 0.000 \\
\hline 14 & 0.072 & -0.067 & 138.89 & 0.000 \\
\hline 15 & 0.029 & -0.073 & 138.95 & 0.000 \\
\hline 16 & -0.018 & -0.075 & 138.97 & 0.000 \\
\hline 17 & -0.076 & -0.084 & 139.4 & 0.000 \\
\hline 18 & -0.146 & -0.099 & 141.02 & 0.000 \\
\hline 19 & -0.202 & -0.014 & 144.3 & 0.000 \\
\hline 20 & -0.252 & -0.04 & 149.64 & 0.000 \\
\hline
\end{tabular}

Source: Authors' Computations using Eviews 10.0, 2021.

Table 2 shows the correlogram Q-statistics which was also used as a confirmation of the presence of $\mathrm{ARCH}$ effect. The findings show that the probability values for $\mathrm{AC}, \mathrm{PAC}$ and $\mathrm{Q}$-stat are all zeros indicating that the P-value is significant assuming $5 \%$ level of significance $(P<0.05)$. This implies the rejection of null hypothesis that stated that there is no $\mathrm{ARCH}$ effect. 


\subsubsection{The GARCH effect}

Table 3: The GARCH effect result

\begin{tabular}{|c|r|r|r|r|}
\hline Variable & Coefficient & Std. Error & z-Statistic & Prob. $^{*}$ \\
\hline C & 5.577721 & 0.444528 & 12.54752 & 0.0000 \\
\hline EXRVOL & -0.015610 & 0.001680 & -9.289508 & 0.0000 \\
\hline GARCH & 0.125077 & 0.361184 & 0.346297 & 0.0291 \\
\hline \multicolumn{5}{|c|}{ Variance Equation } \\
\hline C & 0.880468 & 0.174712 & 5.039530 & 0.0000 \\
\hline RESID(-1)^2 & 0.907258 & 0.018434 & 49.21476 & 0.0000 \\
\hline GARCH(-1) & 0.134863 & 0.063555 & 2.122003 & 0.0434 \\
\hline
\end{tabular}

Source: Authors' Computations using Eviews 10.0, 2021.

Table 3 shows the $\operatorname{GARCH}(1,1)$ effect result. The findings show that there is a high volatility of exchange rate at 5 percent level of significant. The coefficients of $\mathrm{ARCH}$ and $\mathrm{GARCH}$ term are positive and both are statistically significant at $5 \%$ level of significance since their probability values are less that $0.05(\mathrm{P}<0.05)$. Also, the coefficient of exchange rate volatility $(E X R V O L)$ has a negative sign and statistical significance at $5 \%$ level. This shows that there is a negative and significant relationship between exchange rate volatility and the performance of the manufacturing sector in Nigeria. Finally, a close examination on the result shows that the coefficient of $A R C H$ term is higher than that of the GARCH term indicating that volatility in the exchange rate for the periods under consideration tends to be more extreme. The implication of the positive and significant values of the coefficient of $\mathrm{ARCH}$ and $\mathrm{GARCH}$ term validate the fact that exchange rate volatility of the past periods influence the exchange rate volatility of the current period. 


\subsection{Empirical Analysis}

\subsubsection{Unit Root Test}

Table 4: Augmented Dickey Fuller Test at level and First Difference

\begin{tabular}{|c|c|c|c|c|c|c|}
\hline \multirow{2}{*}{ VARIABLES } & \multirow{2}{*}{$\begin{array}{l}\text { ADF TEST } \\
\text { STATISTICS }\end{array}$} & \multicolumn{3}{|c|}{ ADF CRITICAL VALUE } & \multirow{2}{*}{$\begin{array}{l}\text { ORDER OF } \\
\text { INTEGRATION }\end{array}$} & \multirow{2}{*}{ REMARKS } \\
\hline & & $\begin{array}{c}1 \% \\
\text { Level }\end{array}$ & $\begin{array}{c}5 \% \\
\text { level }\end{array}$ & $\begin{array}{l}10 \% \\
\text { level }\end{array}$ & & \\
\hline MAN & -0.681749 & -3.610453 & -2.938987 & -2.607932 & $\mathrm{I}(0)$ & Non-Stationary \\
\hline EXRVOL & 2.169273 & -3.610453 & -2.938987 & -2.607932 & $\mathrm{I}(0)$ & Non-Stationary \\
\hline IMP & -1.438627 & -3.621023 & -2.943427 & -2.610263 & $\mathrm{I}(0)$ & Non-Stationary \\
\hline GCF & -1.859068 & -3.621023 & -2.943427 & -2.610263 & $\mathrm{I}(0)$ & Non-Stationary \\
\hline INTR & -2.073461 & -3.610453 & -2.938987 & -2.607932 & $\mathrm{I}(0)$ & Non-Stationary \\
\hline INFL & -3.569970 & -3.615588 & -2.941145 & -2.609066 & $\mathrm{I}(0)$ & Non-Stationary \\
\hline
\end{tabular}

\begin{tabular}{|c|c|c|c|c|c|c|}
\hline \multirow{2}{*}{ VARIABLES } & \multirow{2}{*}{$\begin{array}{l}\text { ADF TEST } \\
\text { STATISTICS }\end{array}$} & \multicolumn{3}{|c|}{ ADF CRITICAL VALUE } & \multirow{2}{*}{$\begin{array}{l}\text { ORDER OF } \\
\text { INTEGRATION }\end{array}$} & \multirow{2}{*}{ REMARKS } \\
\hline & & $\begin{array}{c}1 \% \\
\text { Level }\end{array}$ & $\begin{array}{l}5 \% \\
\text { level }\end{array}$ & $\begin{array}{l}10 \% \\
\text { level }\end{array}$ & & \\
\hline $\mathrm{D}(\mathrm{IFD})$ & -5.677333 & -3.610453 & -2.938987 & -2.607932 & $\mathrm{I}(1)$ & Stationary* \\
\hline $\mathrm{D}(\mathrm{EXRVOL})$ & -4.120970 & -3.615588 & -2.941145 & -2.609066 & $\mathrm{I}(1)$ & Stationary* \\
\hline $\mathrm{D}(\mathrm{IMP})$ & -7.928241 & -3.615588 & -2.941145 & -2.609066 & $\mathrm{I}(1)$ & Stationary* \\
\hline $\mathrm{D}(\mathrm{GCF})$ & -4.209479 & -3.626784 & -2.945842 & -2.611531 & $\mathrm{I}(1)$ & Stationary* \\
\hline $\mathrm{D}(\mathrm{INTR})$ & -6.528727 & -3.621023 & -2.943427 & -2.610263 & $\mathrm{I}(1)$ & Stationary* \\
\hline $\mathrm{D}(\mathrm{INFL})$ & -6.464284 & -3.610453 & -2.938987 & -2.607932 & $\mathrm{I}(1)$ & Stationary* \\
\hline
\end{tabular}

Source: Authors' Computations using Eviews 10.0, 2021.

The findings of the Augmented Dickey Fuller (ADF) test in above table 4 show that manufacturing performance (MAN), exchange rate volatility (EXRVOL), import (IMP), gross capital formation (GCF), interest rate (INTR) and inflation rate (INFL) were found to be stationary at first differenced using $1 \%, 5 \%$ and $10 \%$ level of significance. 


\subsubsection{Bound Test Approach to Cointegration}

The study applied the ARDL Bounds test to test whether there is a long run relationship among variables. The model has an unrestricted trend with no constant. The results are reported in Table 5 below:

Table 5: Bounds test results

\begin{tabular}{|c|c|c|c|c|}
\hline Significance & $\begin{array}{l}\text { Lower bound } \\
\text { value }\end{array}$ & Upper bound value & $\begin{array}{c}\text { F-Statistic } \\
\text { value }\end{array}$ & Null Hypothesis \\
\hline $10 \%$ & 2.26 & 3.35 & \multirow{4}{*}{3.984460} & No cointegration \\
\hline $5 \%$ & 2.62 & 3.79 & & No cointegration \\
\hline $2.50 \%$ & 2.96 & 4.18 & & No cointegration \\
\hline $1 \%$ & 3.41 & 4.68 & & No cointegration \\
\hline
\end{tabular}

Source: Authors' Computations using Eviews 10.0, 2021.

$\mathrm{H}_{0}$ : There is no cointegration

$\mathrm{H}_{1}$ : There is cointegration

\section{Decision Rule}

Probabilities $>0.05$ accept the null hypothesis

Probabilities $<0.05$ reject the null hypothesis

The results for the Bounds test in table 5 above reveals that there is a long run relationship among the variables. This is because the F-statistics value (3.984460) is greater than upper Bounds critical values at $5 \%$ level of significant, and thus the null hypothesis of no cointegration is rejected. 


\subsubsection{ARDL Model Estimate}

Though there is a presence of cointegration, it was necessary to estimate the long-run ARDL in order to calculate the elasticities. Thus, the long run ARDL was estimated or unrestricted ECM was estimated and the results are presented in Table 4 below.

Table 6: ARDL Estimation Result

\begin{tabular}{|c|r|r|r|r|}
\hline Variable & Coefficient & Std. Error & t-Statistic & Prob. $^{*}$ \\
\hline Short run Estimate & \multicolumn{5}{|l|}{} \\
\hline $\mathrm{D}(\mathrm{EXRVOL})$ & -0.124308 & 0.039851 & -3.119255 & 0.0058 \\
\hline $\mathrm{D}(\mathrm{IMP})$ & 0.025459 & 0.025450 & 1.000338 & 0.3247 \\
\hline $\mathrm{D}(\mathrm{GCF})$ & 0.160579 & 0.040368 & 3.977874 & 0.0004 \\
\hline $\mathrm{D}(\mathrm{INTR})$ & -0.090165 & 0.022192 & -4.062804 & 0.0000 \\
\hline $\mathrm{D}(\mathrm{INFL})$ & -0.001287 & 0.011075 & -0.116168 & 0.9082 \\
\hline ECM & -0.664381 & 0.226562 & -2.932436 & 0.0062 \\
\hline Long run Estimate & -0.101166 & 0.032438 & -3.118696 & 0.0063 \\
\hline EXRVOL & 0.019224 & 0.000225 & 0.997019 & 0.3262 \\
\hline IMP & 0.607378 & 0.166138 & 3.655871 & 0.0009 \\
\hline GCF & -0.341042 & 0.141761 & -2.405749 & 0.0318 \\
\hline INTR & -0.006866 & 0.041519 & -0.117206 & 0.9074 \\
\hline C & -4.105596 & 3.715381 & -1.105027 & 0.2774 \\
\hline R-squared = 0.893 Adjusted R-squared = 0.867 & F-test = 34.696 DW-stat = 2.199 \\
\hline
\end{tabular}

\section{Source: Authors' Computations using Eviews 10.0, 2021.}

Table 6 above shows the Autoregressive distributed lag model results, the long run estimates shows that exchange rate volatility, interest rate and inflation rate has a negative impact on the performance of manufacturing sector at about $10 \%, 34 \%$ and $1 \%$ respectively in the long run while import and gross capital formation have a positive effect on manufacturing performance in the long run at about $2 \%$ and $60 \%$ respectively. Also, exchange rate volatility, gross capital formation and interest rate were found to have a significant impact on manufacturing performance while import and inflation were found to be non-significant. The findings also show that in the short run that volatility in exchange rate is negatively and significantly related to the performance of manufacturing sector in Nigeria. This result validates the findings of $\mathrm{GARCH}$ effect which shows a negative and significant relationship between exchange rate volatility and manufacturing performance in Nigeria.

Furthermore, the coefficient of Error correction term (ECM) shows that about 66 percent of the disparities between the actual and the equilibrium value of manufacturing performance is 
corrected each year. Also, the coefficient of determination $\left(R^{2}\right)$ is 0.893 which shows that about 89 percent variations in the manufacturing performance were explained by the independent variables. The F-stat is 34.69 shows that the overall test is significant. Finally, the DurbinWatson statistics is 2.199 and it shows that there is no autocorrelation in the model.

\subsection{Post- Diagnostic Test}

\subsubsection{Confirmation of the absence of Serial Correlation}

Table 7: Breusch-Godfrey Serial Correlation LM Test

Breusch-Godfrey Serial Correlation LM Test

\begin{tabular}{|l|l|l|l|}
\hline F-statistic & 2.549713 & Prob. F(2,30) & 0.0949 \\
\hline Obs ${ }^{*}$ R-squared & 5.666121 & Prob. Chi-Square(2) & 0.0688 \\
& & & \\
\hline
\end{tabular}

Source: Authors' Computations using Eviews 10.0, 2021.

$\mathrm{H}_{0}$ : The residuals are not serially correlated

$\mathrm{H}_{1}$ : The residuals are serially correlated

\section{Decision Rule}

Probabilities $>0.05$ accept the null hypothesis

Probabilities $<0.05$ reject the null hypothesis

Table 7 above present the result of Breusch-Godfrey Serial Correlation LM Test. Based on the findings, the probability of the chi-square (2) is 0.068 and this is greater than 0.05 at $5 \%$ significance level and therefore the null hypothesis is accepted. This implies and therefore confirms the absence of serial correlation. 


\subsubsection{Confirmation of Absence of Heteroscedasticity}

Table 8: Breusch-Pagan-Godfrey Heteroscedasticity Test

\begin{tabular}{|l|l|l|l|}
\hline \multicolumn{3}{|l|}{ Breusch-Pagan-Godfrey Heteroscedasticity Test } \\
\hline F-statistic & 1.093501 & Prob. F(6,32) & 0.3875 \\
\hline Obs*R-squared & 6.635701 & Prob. Chi-Square(6) & 0.3559 \\
\hline Scaled explained SS & 5.353148 & Prob. Chi-Square(6) & 0.4994 \\
\hline
\end{tabular}

Source: Authors' Computations using Eviews 10.0, 2021.

$\mathrm{H}_{0}$ : Homoscedasticity

$\mathrm{H}_{1}$ : Heteroscedasticity

Decision Rule

Probabilities $>0.05$ accept the null hypothesis

Probabilities $<0.05$ reject the null hypothesis

The above table 8 present the Breusch-pagan-Godfrey Heteroscadaticity test, the probability of chi-square (6) is 0.3559 and this is greater than 0.05 at $5 \%$ significant level and therefore the null hypothesis is accepted. This implies and therefore confirms the absence of heteroscedasticity in the model. In essence, they have constant variance in repeated sampling. 


\subsection{Conclusion}

This study examined the impact exchange rate volatility on manufacturing sector performance in Nigeria from 1981 to 2020 using ARCH/GARCH model and Autoregressive Distributed Lag Model (ARDL) as the major statistical technique of analysis. From the findings, the $\mathrm{ARCH} / \mathrm{GARCH}$ model confirms that there is a high volatility of exchange rate in Nigeria which was validated by their coefficients which were both positive and statistically significant at $5 \%$ level of significance. Also, the findings show that there is a negative and significant relationship between exchange rate volatility and the performance of the manufacturing sector in Nigeria. The ARDL results show that volatility of exchange rate, interest rate and inflation rate has a negative impact on the performance of manufacturing sector in the long run while import and gross capital formation have a positive effect on manufacturing performance in the long run. Also, exchange rate volatility, gross capital formation and interest rate were found to have a significant impact on manufacturing performance while import and inflation were found to be non-significant. The findings also show that in the short run that volatility in exchange rate is negatively and significantly related to the performance of manufacturing sector in Nigeria. The study concludes that the monetary authorities should formulate a policy framework that will be targeted at improving and stabilizing naira exchange rate. It has been established that manufacturing sector is one of the major key sectors in the many economies of the world. Therefore, the need for Nigerian government to appropriate more funds to the manufacturing sector should be encouraged. Finally, interest on lending should be reduced to encourage investment both locally and internationally. 


\section{Declarations}

\section{Ethics approval and consent to participate}

Not applicable

\section{Consent for Publication}

Not applicable

\section{Availability of data and materials}

The data for this study were sourced from the database of Central Bank of Nigeria (CBN) Statistical Bulletin (https:/www.cbn.gov.ng) and National Bureau of Statistics (NBS).

\section{Competing interests}

The author declares that there are no competing interests associated with this manuscript.

\section{Funding}

I hereby declare that there was no funding received for this manuscript.

\section{Author's contributions}

The author was the overall contributor to the development of all the sections in this manuscript.

\section{Acknowledgements}

The author is highly indebted to the editors and reviewers for their guidance in not only ensuring that this manuscript is scholarly but also gets published accordingly. 


\section{REFERENCES}

Adofu, I., Taiga, U .U. \& Tijani, Y. (2015). Manufacturing sector and economic growth in Nigeria. Donnish Journal of Economics and International Finance, 1(1), 1-6.

Adegbemi, B. O. (2018). Macroeconomic dynamics and the manufacturing output in Nigeria. Mediterranean Journal of Social Sciences, 9(2), 43-54.

Adebayo, O. E. (2010). The role of industrial sector in the economic development of Nigeria. Journal of Management and Society, 1(5), 9-16.

Akinlo, E. A. \& Adejumo, V. A. (2014). Exchange rate volatility and non-oil exports in Nigeria. International Business and Management, 9(2), 70-79.

Calvo, G.A., Reinhart, C.M., \& Vegh, C.A., (1995). Targeting the real exchange rate: theory and evidence, Journal of Development Economics, 47(1), 97-133.

Central Bank of Nigeria (2020), Annual report and statement of accounts CBN, Abuja Central.

Central Bank of Nigeria (2011). Exchange rate management in Nigeria, Understanding Monetary Policy Series, No. 8, Abuja.

Central Bank of Nigeria (2016). Foreign exchange rate, Research Department - Education in Economics Series, No. 4, Abuja.

Dickson, S.O. (2014) Industrialisation and sustainable development in Nigeria. The International Journal of Social Sciences and Humanities Invention, 1(3), 142-154.

Dornbusch, R. (1975). A portfolio balance model of the open economy, Journal of monetary economics, 1(1), 3-20.

Enekwe, C. I., Ordu, M. M. \& Nwoha, C. (2013). Effect of exchange rate fluctuations on manufacturing sector in Nigeria. European Journal of Business and Management, 5(22), 67-73.

Ezenwakwelu, C.A. (2017), International business management. Enugu: Immaculate publications Ltd.

Fakiyesi, O. A. (2015), Issues in money, finance and economic management. Lagos: University Press.

Falaye, J. A., Eseyin, O., Otekunrin, A., Asamu, F., Ogunlade, P., Egbide, B., \& Rasak, B. (2018). Impact of exchange rate on the manufacturing sector in Nigeria.

Gbosi, A.N (2003). Financial sector instability and challenges to Nigeria's Monetary authorities. Port Harcourt; African heritage publishers.

Hunegnaw, F. B. (2018). Real exchange rate and manufacturing export competitiveness in Eastern Africa. 
Kiguel, N., \& Ghei, M.O. (1993). Devaluation in low inflation economies. World Bank.

Mojekwu, J. N., Okpala, O. P \& Adeleke, I (2011). Comparative analysis of models of monetary exchange rates in Nigeria, African Journal of Business Management, 5 (34), 1302513029.

Mundel, A. Robert (1961). The Monetary Dynamics of International Adjustment Under Fixed and Flexible Exchange Rate, Quarterly Journal of Economic, 74(1), 4-19.

Mckinnon, R. C. (1963). Optimal Currency Areas, American Economic Review, 53(3), 5-28.

Nwokoro, A. N. (2017). Foreign exchange and interest rates and manufacturing output in Nigeria. International Journal of Business \& Law Research, 5(1), 30-38.

Nsofo, E. S., Takson, S. M. \& Ugwuegbe, S. U. (2017). Modeling exchange rate volatility and economic growth in nigeria. Noble International Journal of Economics and Financial Research, 2(6), 88- 97.

Okorontah, C. F. \& Odoemena, I. U. (2016). Effects of exchange rate fluctuations on economic growth of Nigeria, International Journal of Innovative Finance and Economics Research $4(2), 1-7$.

Olufayo, M. B. \& Fagite B.A. (2014). Exchange rate volatility and sectorial export of Nigeria: Case of oil and non-oil sectors. Journal of Economics and Sustainable Development, $5(10), 66-69$.

Opaluwa, D, Umeh, J.C. \& Ameh, A.A (2012). The effect of exchange rate fluctuations on the Nigerian manufacturing sector. African Journal of Business Management, 4(14), 2994 2998.

Oriji, A., Ogbuabor, J. E., Okeke, C., \& Oriji, O. A. (2019). Another side of the coin: exchange rate movements and the manufacturing sector in Nigeria. https://jour nals.sagepub.com/doi/abs/10.1177/0974930618811499.

Rahim, M., Paulo, C. R \& Masoud, Y (2018). Forecasting daily exchange rates: a comparison between SSA and MSSA.

Ugwu, O. J. (2017). Foreign exchange rate dynamics and manufacturing firms' performance in Nigeria. International Journal of Humanities and Social Science Invention, 6(9), 9-14. 
